\section{Michigan Technological

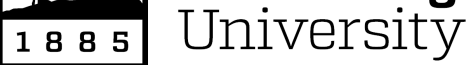

Michigan Technological University Digital Commons @ Michigan Tech

\title{
Optimization of Annealing Cycles for Electric Output in Outdoor Conditions for Amorphous Silicon Photovoltaic - Thermal Systems
}

Joseph Rozario

Michigan Technological University

Joshua M. Pearce

Michigan Technological University

Follow this and additional works at: https://digitalcommons.mtu.edu/materials_fp

\section{Recommended Citation}

Joseph Rozario and Joshua M. Pearce, Optimization of annealing cycles for electric output in outdoor conditions for amorphous silicon photovoltaic-thermal systems. Applied Energy, 148, pp. 134-141 (2015). http://digitalcommons.mtu.edu/materials_fp/45 


\title{
Optimization of Annealing Cycles for Electric Output in Outdoor Conditions for Amorphous Silicon Photovoltaic - Thermal Systems
}

\author{
Joseph Rozario $^{\mathrm{a}}$ and Joshua M. Pearce ${ }^{\mathrm{b}, *}$ \\ ${ }^{a}$ Department of Electrical \& Computer Engineering, Michigan Technological University, \\ Houghton, MI 49931, USA \\ ${ }^{b}$ Department of Materials Science \& Engineering, Michigan Technological University, \\ Houghton, MI 49931, USA \\ *corresponding author:pearce@mtu.edu
}

\begin{abstract}
Previous studies with fixed operating temperatures have shown that hydrogenated amorphous silicon (a-Si:H) was a promising absorber layer for solar photovoltaic - thermal (PVT) systems because of a) a low temperature coefficient and b) the opportunity to reverse light induced degradation with thermal annealing. This study further refined the simulation of the optimal dispatch strategy for a-Si:H based PVT by studying annealing cycles and analysis of the degradation at other operating temperatures controlled by the varying ambient temperatures. Four representative case studies were evaluated for the combinations of high and low solar flux and high and low average ambient temperature. Electrically-optimized dispatch strategies are found for a range of PVT thermal insulating effectivenesses. The results showed significantly more electricity generation in all the case study representative regions except for areas dominated by low temperatures and low solar fluxes. These results indicate that a-Si:H PV performance can be improved in most populated regions in the world by integrating it into a PVT device and using spike annealing to reverse light-induced degradation effects. The model presented in this paper uses publicly-available data to implement suitable dispatch strategies and execute virtual performance analysis of PVT for any geographic location in the world.
\end{abstract}

Keywords : amorphous silicon; photovoltaic; solar thermal; PVT; solar photovoltaic-thermal system; thermal annealing 


\section{Introduction}

Crystalline silicon (c-Si) solar photovoltaic (PV) cells with commercialized conversion efficiencies in the range of high teens to low twenties are the most widely used on the market, representing about $80-90 \%$ of the world total PV cell production [1]. High-efficiency c-Si PV cells have advantages in performance and area-requirements and are thus normally used as the absorber in hybrid solar photovoltaic thermal (PVT) systems [2]. PVT systems combine a photovoltaic cell with a solar thermal collector and perform dual operation: 1) converts light energy directly into electricity and 2) captures the remaining energy normally considered waste heat from the PV module for domestic hot water or other heating needs. The combined capture of both heat and electricity allow these devices to have higher exergy and thus be more overall spatially energy efficient than either stand-alone solar photovoltaic or solar thermal systems [3]. This dual use enables PVT technology to provide benefits in terms of energy, exergy efficiency, and in some cases cost [3-12].

However, there is a inherent technical contradiction with the operating temperature of PVT devices. Photovoltaic cell efficiency falls with the rise in temperature and as c-Si has a large thermal coefficient $(-0.45 \% / K)$ [13] using it at acceptable operating temperatures as a PVT absorber material leads to poor performance of the thermal component and thus the whole system non-optimized [14-18]. This is because the conventional PVT system is designed to carry heat away from the modules thereby cooling the cells and thus improving their electricity conversion efficiency by lowering resistance [9]. Although this is beneficial for the PV, it causes the thermal component to under-perform compared to a stand-alone solar thermal collector allowed to operate at higher temperatures. However, thin film hydrogenated amorphous silicon (a-Si:H) PV have a thermal coefficient of only $-0.13 \% / \mathrm{K}$ [13], making it acceptably functional at higher temperatures. PV materials with low temperature coefficients such as a-Si:H PV allow the PVT to be operated at high temperatures, promoting a more unified and potentially optimized PVT system [19-21].

The two primary challenges to widespread commercialization of a-Si:H PV in general are relatively low efficiencies ( $10 \%)$ and light-induced degradation of performance known as the Staebler-Wronski effect (SWE) [22]. SWE is associated with increased defect state density in the mobility gap of the material when exposed to sunlight, which cause a drop in power 
generation/conversions efficiency with light exposure time until a steady state (degraded steady state or DSS) is reached [22-27]. SWE is reversible with annealing at elevated temperatures [2227]. Recent, experiments have shown that PVT operating temperatures can be used to provide regular high temperature spike thermal annealing (e.g. $1 \mathrm{~h}$ at $100^{\circ} \mathrm{C}$ on a $12 \mathrm{~h}$ cycle) is adequate to reduce the number of defect states and provide a significantly higher electricity output [20]. In order to improve the performance of the PVT system further a previous study investigated the impact of annealing cycles in different geographic locations with real solar flux data and showed that at standard and sustained PV operating temperatures one anneal pulse per day provided the largest electrical output through the year [28]. Overall the results showed additional electricity generation is possible over the year with an appropriate dispatch strategy of spike thermal annealing cycles. With operating temperatures for standard testing conditions $\left(25^{\circ} \mathrm{C}\right)$, PV operational $\left(50^{\circ} \mathrm{C}\right)$ and PVT operational $\left(90^{\circ} \mathrm{C}\right.$ as this is the operational temperature of solar thermal systems) provided 23\%, 10\%, and 1.2\% additional electricity generation over a year, respectively. Although it is possible to sometimes fix the operating temperature of the PVT the ambient temperature that the system operates in can fluctuate widely. To take this real-world consideration this paper further refines the simulation of the optimal dispatch strategy for a-Si:H based PVT by studying annealing cycles and analysis of the degradation at other operating temperatures controlled by the ambient temperature. Four case studies are evaluated for the combinations of high and low solar flux and high and low average ambient temperature. Optimal dispatch strategies are found for a range of PVT thermal insulating effectivenesses. The results are discussed and conclusions are drawn about the optimal dispatch strategy for PVT devices in any geographic region.

\section{Background SWE Degradation Associated Parameters}

Previous work has introduced the a-Si:H PV SWE degradation kinetics associated parameters $k_{d s s}$ and $u_{d s s}$ [28], which quantify the SWE degradation rates and magnitude of reduced PV performance under illumination. The parameter $\mathrm{k}_{\mathrm{dss}}$ is associated with the magnitude of the DSS and $u_{d s s}$ is associated with the degradation rate. These parameters were introduced in the PV max power generation equation in order to modify the equation for PVT and incorporate the effect of SWE into it [28]. Exponential fits [28] to experimental data [27] showing SWE to 
the DSS were obtained at sustained operating temperatures $25{ }^{\circ} \mathrm{C}, 50{ }^{\circ} \mathrm{C}$, and $90{ }^{\circ} \mathrm{C}$ for a-Si:H PV cell active layer thickness of $630 \mathrm{~nm}$ under 1 sun illumination were used to derive $\mathrm{k}_{\mathrm{dss}}$ and $u_{d s s}$

When the irradiance is constant, it is notable that the exponential degradation rate and the DSS power generation both depend on the operating temperature. To take into account the effect of operating temperature outside of these fixed values, the degradation rate and the steady state power generation is required to make a function of temperature. This is accomplished in this paper to expand the geographic validity of the PVT spike annealing dispatch strategy to any location.

\section{Methods}

\subsection{Derivation of Temperature Dependent $\mathbf{k}_{\mathrm{dss}}$ and $\boldsymbol{u}_{\mathrm{dss}}$}

The degradation associated parameters $\mathrm{k}_{\mathrm{dss}}$ and $u_{d s s}$ are represented as a function of temperature in order to extrapolate PVT performance in any region (ambient temperature dependent operation). These parameters both have unique relationship with temperature. It has also been experimentally determined that $\mathrm{k}_{\mathrm{dss}}$ decreases and $u_{d s s}$ increases with increasing temperature. In addition as the temperature is increased the power generation reaches steady state with a faster degradation rate (requires less time) and this DSS is higher at higher temperatures. As a first approximation the changes in the parameter values have been considered to be changing linearly in the range between the experimentally measured temperatures. Equation (1) and (2) linearly calculate the values of $\mathrm{k}_{\mathrm{dss}}$ and $u_{\mathrm{dss}}$ in the intermediate regions between $25{ }^{\circ} \mathrm{C}$ to $50{ }^{\circ} \mathrm{C}$ and $50{ }^{\circ} \mathrm{C}$ to $90^{\circ} \mathrm{C}$ [28] and Figures 1 and 2 shows the corresponding graphs.

$$
\begin{aligned}
& k_{d s s x}=k_{d s s 1}+\frac{k_{d s s 2}-k_{d s s 1}}{T_{2}-T_{1}} \times\left(T_{x}-T_{1}\right) \\
& u_{d s s x}=u_{d s s 1}+\frac{u_{d s s 2}-u_{d s s 1}}{T_{2}-T_{1}} \times\left(T_{x}-T_{1}\right)
\end{aligned}
$$


The values of the parameters at temperature $\mathrm{x}$ outside the range of $25{ }^{\circ} \mathrm{C}$ to $90{ }^{\circ} \mathrm{C}$ are again calculated by extending the lines linearly. Temperature 1 and 2 are the known (measured temperatures).

\subsection{Geographic Expansion and Simulation Mechanism Updates}

Previous simulations were confined to four specific cities in United States [28]. In order to expand the optimization maps for the performance of the PVT it is required to expand the modeling range by including more solar and weather data collected from worldwide solar resources and satellites. As a primary approach in the present work the solar data for regions all over U.S. (including Alaska and Hawaii) and Canada has been included in the simulation. Specifically the hourly solar irradiance and temperature data from the U.S. Air Force weather stations has been used [29, 30], National Renewable Energy Lab (NREL)'s Solar Prospector [31] and METSTAT-modeled global horizontal solar irradiation data [32] which indicates the total amount of direct and diffuse solar radiation (METSTAT-modeled) received on a horizontal surface during the 60-minute period ending at the timestamp. The Canadian data was obtained from the National Resources Canada (NRCAN) website [33]. The hourly ambient temperature data was utilized in the simulation hence $\mathrm{k}_{\mathrm{dss}}$ and $u_{\text {dss }}$ fluctuate in accordance with the temperature. Users can input solar data in the simulation using either known USAF station ID or geographic coordinates and the open-source script is available [34] that gives the exact PVT output at different operating conditions and dispatch strategies.

\subsection{Inputs for Case Study Locations}

For a particular location as the temperature varies the degradation associated parameters also vary hourly. The analysis utilizes time series temperature data along with the hourly solar irradiance data. Here four specific locations with different atmospheric conditions were:

1. High solar flux/high temperature

2. High solar flux/low temperature

3. Low solar flux/high temperature

4. Low solar flux/low temperature 
The selected cities are summarized in Table 1. Normally the amount of incidence of solar flux depends on the geographic coordinate, incident angle and air mass/optical path of incidence. On the other hand, the temperature mostly depends on the humidity and air mass.

Table 1: Case study locations based on atmospheric criteria

\begin{tabular}{|l|l|l|}
\hline & High Solar Flux & Low Solar Flux \\
\hline High Temperature & Casa Grande, Arizona & Apalachicola, Florida \\
\hline Low Temperature & Aspen, Colorado & Anchorage, Alaska \\
\hline
\end{tabular}

The time series hourly data sets starting from January 1st, 2002 to December 31st, 2002 were utilized in the simulation. The details of the four case study cities are provided in Table 2. It is to be noted that the average hourly temperature in this cities are lower than $25^{\circ} \mathrm{C}$ which was the lowest operating temperature in the consistent operating temperature PVT dispatch model previously investigated.

Table 2. Summary of climate for case study cities

\begin{tabular}{|c|c|c|c|c|}
\hline City & Coordinates & $\begin{array}{c}\text { Average Hourly } \\
\text { Temperature (for } \\
\text { the year 2002) } \\
{\left[{ }^{\circ} \mathrm{C}\right]}\end{array}$ & $\begin{array}{c}\text { Altitude } \\
\text { [ft] }\end{array}$ & $\begin{array}{c}\text { Average hourly } \\
\text { solar irradiance } \\
{\left[\mathrm{W} / \mathbf{m}^{2}\right]}\end{array}$ \\
\hline $\begin{array}{c}\text { Anchorage (Anchorage } \\
\text { Borough, Alaska) }\end{array}$ & $\begin{array}{l}61.2167^{\circ} \mathrm{N}, \\
149.9000^{\circ} \mathrm{W}\end{array}$ & -3.4 & 102 & 100.8 \\
\hline $\begin{array}{c}\text { Casa Grande (Pinal } \\
\text { County, Arizona) }\end{array}$ & $\begin{array}{l}32.8858^{\circ} \mathrm{N}, \\
111.7439^{\circ} \mathrm{W} \\
\end{array}$ & 21.6 & 1,398 & 251.4 \\
\hline $\begin{array}{c}\text { Apalachicola (Franklin } \\
\text { County, Florida) }\end{array}$ & $\begin{array}{l}29.7253^{\circ} \mathrm{N} \\
84.9925^{\circ} \mathrm{W}\end{array}$ & 20.4 & 13 & 215.0 \\
\hline $\begin{array}{c}\text { Aspen (Pitkin County, } \\
\text { Colorado) }\end{array}$ & $\begin{array}{l}39.1922^{\circ} \mathrm{N}, \\
106.8244^{\circ} \mathrm{W}\end{array}$ & 5.2 & 7,890 & 193.8 \\
\hline
\end{tabular}


The daily average solar flux and the temperature reading in the four cases study cities is shown in Figures 3 and 4, respectively. Average solar irradiance per day for the cities (Anchorage, Casa Grande, Apalachicola, and Aspen) are 2.42, 6.03, 5.16, and 4.65 sun hours respectively. The peak sun hour with high flux lies in between 900 to 1600 hrs when the flux is higher than $250 \mathrm{~W} / \mathrm{m}^{2}$. Also it is noteworthy that during these hours the temperature is comparatively low, which means the degradation occurs at a slow rate.

\section{Results}

\subsection{Simulation at Sustained Operating Temperature}

As an initial step of the analysis was performed at sustained operating temperatures where the degradation parameters are constant. The output obtained for the sustained operating temperature simulation in the four representative cities is shown in Figure 5, 6, 7 and 8.. In all the cases the $90^{\circ} \mathrm{C}$ operating temperature with a single anneal per day provides the maximum power output.

Table 3 Normalized max electricity generation with respect to $25^{\circ} \mathrm{C}$ max electricity at sustained operating temperatures (anneal cycle: once every day).

\begin{tabular}{|c|c|c|c|}
\hline Cities & $\begin{array}{c}\text { Normalized Max } \\
\text { Electricity at } \mathbf{2 5}{ }^{\mathbf{}} \mathbf{C}\end{array}$ & $\begin{array}{c}\text { Normalized Max } \\
\text { Electricity at } \mathbf{5 0}{ }^{\mathbf{}} \mathbf{C}\end{array}$ & $\begin{array}{c}\text { Normalized Max } \\
\text { Electricity at } \mathbf{9 0}{ }^{\mathbf{}} \mathbf{C}\end{array}$ \\
\hline Anchorage, AK & 1 & 1.0025 & 1.0130 \\
\hline Casa Grande, AZ & 1 & 1.0019 & 1.0088 \\
\hline Apalachicola, FL & 1 & 1.0017 & 1.0087 \\
\hline Aspen, Colorado & 1 & 1.0076 & 1.0103 \\
\hline
\end{tabular}

\subsection{Sensitivity and Outdoor Operating Conditions}

By comparison to fixed operating temperatures, the ambient temperature performance of PVT is more complicated. For the performance analysis an environmental insulation based sensitivity study is carried out as summarized by Table 4.

Table 4. PVT Operating Temperature Sensitivity Inputs as a Function of Insulation Level

\begin{tabular}{|l|l|l|}
\hline Cases & Operating Temperature & Insulation Level \\
\hline Case I & $90{ }^{\circ} \mathrm{C}$ & High insulation and control \\
\hline Case II & Ambient Temperature & None (ambient) \\
\hline Case III & Ambient Temperature $+25^{\circ} \mathrm{C}$ & Low \\
\hline Case IV & Ambient Temperature $+50^{\circ} \mathrm{C}$ & Medium \\
\hline
\end{tabular}


The effect of insulation level on PVT output as a function of the operating conditions dependent on ambient temperature $\left(-10^{\circ} \mathrm{C}\right.$ to $\left.130^{\circ} \mathrm{C}\right)$ is shown in Figure 10 .

\subsection{Simulation at Outdoor Operating Conditions}

Outdoor simulations were performed by taking into account the outdoor operating case studies along with the spike anneal cycles. The overall electricity generation for the representative cities at outdoor operating conditions are shown in Figures 11, 12, 13 and 14. From the Figures it can be seen that in each region the PVT panels generate more electricity when operated at ambient temperatures than at STC, which as pointed out before is on average lower than $25^{\circ} \mathrm{C}$ in each city. Along with the outdoor operating conditions the simulated annealing cycle cases range from 0 to 6 anneals per day.

In Anchorage, AK (Figure 11) the effect of annealing is very minor and eventually causes a power drop; while operation without annealing gives the maximum power. This behavior can be attributed to the fact that the annual temperature is very low in Alaska ( $-3.4^{\circ} \mathrm{C}$ on average) and at low temperatures the initial degradation rate is very small, although the DSS is worse than for higher temperatures. Also the initial drop in the power during annealing is more significant than the post-anneal power increase. This introduces more energy loss rather than compensating for the light induced degradation. Thus, rapid annealing cycles, which themselves have parasitic losses do not generate additional electricity. In such a case it is more suitable to reduce the frequency of annealing cycles. This is discussed in detail below.

In Casa Grande, AZ (Figure 12) the flux and temperature are comparatively very high. The simulation shows electricity generation is better at outdoor operating temperatures than the other sensitivity controlled outdoor operating conditions. Maximum power is generated with the anneal frequency five times per day. It is similar to the case of Apalachicola, FL (Figure 13), except that the anneal frequency is six times per day. The requirement of a high number of anneals per day in Casa Grande and Apalachicola is due the more rapid degradation of a-Si:H with higher ambient temperatures. Thus more anneal pulses are required to compensate for this power loss due to the creation of "fast" defect states [35,36]. Although the anneal pulses are accompanied with an initial power drop, compared to the SWE degradation and after anneal rapid power boost, this temporary power drop plays a minor in overall device performance. In Aspen, CO (Figure 14) the ambient temperature is low for a reasonable amount of incident solar 
flux in this region. Simulation result shows that a single anneal per day at outdoor operating temperature provides maximum electricity generation.

The max energy output for all the four cities is shown in Figure 15 and includes data for both the sustained operating temperature cases and outdoor operating temperature cases. In all the locations the outdoor operating temperature yield the maximum output. The max energy obtained at Aspen, $\mathrm{CO}$ is close to the max energy obtained at Apalachicola, FL regardless the fact that Florida gets more solar flux than Colorado. This can be attributed to the degradation rate stagnating at locations with lower ambient temperatures. In Colorado, for example, the net electricity generation without annealing is higher than Florida. In Florida the flux is high, but the temperature is relatively high as well, which results in rapid degradation hence the net energy generation without annealing is lower. On the other hand additional power generation due to annealing is more in Florida compared to Colorado. This is because of the rapid degradation of generated power in Florida, which provides an opportunity for the anneal pulses to take place and produce more annealing-associated additional electricity.

The outdoor operating condition simulations are summarized in Table 5. The data represents the output electricity at operating temperature identical to the ambient temperature. The maximum energy obtained for the four cities when annealing is applied and the additional energy generated due to annealing is provided in Table 5 .

Table 5 Maximum electricity generation over a year in the four cities at outdoor operating temperatures.

\begin{tabular}{|c|c|c|c|c|}
\hline Cities & $\begin{array}{c}\text { Max } \\
\text { Electricity } \\
\text { Without } \\
\text { Annealing } \\
\mathbf{( k W h )}\end{array}$ & $\begin{array}{c}\text { Max } \\
\text { Electricity } \\
\text { With } \\
\text { Annealing } \\
\mathbf{( k W h )}\end{array}$ & $\begin{array}{c}\text { Required } \\
\text { Number of } \\
\text { Anneals }\end{array}$ & $\begin{array}{c}\text { Additional } \\
\text { energy } \\
\text { Generation (\%) }\end{array}$ \\
\hline Anchorage, AK & 0.0046 & 0.00457 & $\begin{array}{c}\text { Once every } \\
\text { other day }\end{array}$ & -6.5 \\
\hline Casa Grande, AZ & 0.00737 & 0.0099 & 5 times/day & 34.4 \\
\hline Apalachicola, FL & 0.0063 & 0.00838 & 6 times/day & 33.2 \\
\hline Aspen, CO & 0.0068 & 0.00834 & 1 time/day & 22.5 \\
\hline
\end{tabular}

The following observations summarize the results: 
1. Outdoor operating temperature provides the maximum electricity in all the representative climate cities.

2. To optimize electrical output thermal spike annealing frequency is location dependent due to the ambient temperature and incident solar flux.

3. The effect of annealing is more significant in locations with higher ambient temperatures and this effect appears to be relatively invariant to solar flux.

4. The optimal annealing frequency is higher for regions with higher ambient temperatures.

5. Max energy generation (without annealing at outdoor operating temperatures) is higher in regions with lower ambient temperatures.

6. In locations with extremely low temperatures, the effect of annealing is minor and a-Si:H PVT panels do not necessarily generate additional electricity under rapid annealing cycles if the solar flux is low. As for example, the additional energy generation due to annealing (once every other day) in Anchorage, AK is -6.52 \%, which represents an electricity loss. With a high solar flux and low temperature more moderate gains were seen in Colorado.

\subsection{Appropriate Dispatch Strategy}

A sensitization was performed for the four representative regions on following bases:

1. The frequency of annealing should be as low as possible to reduce the annealing associated thermal energy consumption.

2. The energy generation should be within $2 \%$ of the maximum electricity generation.

The dispatch strategy reasoning for each city is discussed in detail in following segments.

a) Anchorage (Alaska): The outdoor operating temperature simulation result shows that maximum power in Anchorage was obtained without annealing and rapid annealing reduces power generation. The power degradation rate is very low due to extremely low ambient temperature. Hence it is required to reduce the frequency of annealing cycles to obtain power greater than the no anneal case. Using the rules above, annealing only once in a year (8640 hours) was chosen to be an ideal strategy for this city. It resulted in generation of $.000345 \%$ additional energy, which is negligible. Further reduction of annealing frequency i.e. 
annealing once in every two years will possibly provide additional energy. It should be pointed out here that in this case the thermal side of the PVT would rarely be providing useful thermal energy.

b) Casa Grande (Arizona): In Casa Grande the maximum energy was obtained for the strategy that consists of five anneals per day at outdoor operating temperature producing 34.4\% additional energy. Yet a single anneal per day generates 33.4 \% additional energy. This will significantly reduce the annealing associated heating energy consumption.

c) Apalachicola (Florida): In Apalachicola the max energy was obtained for a dispatch strategy consisting six times annealing per day, which resulted in 33.2\% additional energy generation. If the anneal cycle is reduced to one time every day 29.3\% additional electricity generation is still generated, while cutting the annealing associated heating energy consumption down by a factor of six. This compares to the exergy for PV being higher than solar thermal for PV systems by a factor of six.

d) Aspen (Colorado): As can be seen in Table 5, the maximum energy for Aspen was obtained for a single anneal every day. This strategy is also likely to provide a favorable dispatch strategy for Aspen with $22.5 \%$ additional electricity generation.

A comparison is shown in Table 6 of the dispatch strategies that give the maximum electricity with the strategies that gives favorable PVT performance. The calculation only involves electricity generation and hence it is not the complete optimization. The appropriate dispatch strategy in this case can be defined as the strategy that generates electricity close to max possible electricity with lower frequency of anneal cycles. Similarly max energy dispatch strategy refers to the strategy that generates maximum electricity. 
Table 6 Comparison between max energy dispatch strategies and optimized strategies

\begin{tabular}{|c|c|c|c|c|c|c|}
\hline \multirow[t]{2}{*}{ Cities } & \multicolumn{2}{|c|}{$\begin{array}{c}\text { Maximum Electricity Dispatch } \\
\text { Strategy }\end{array}$} & \multicolumn{4}{|c|}{ Appropriate Dispatch Strategy } \\
\hline & $\begin{array}{l}\text { Required Number } \\
\text { of Anneals }\end{array}$ & $\begin{array}{c}\text { Additional } \\
\text { energy } \\
\text { Generation } \\
(\%)\end{array}$ & $\begin{array}{c}\text { Required } \\
\text { Number of } \\
\text { Anneals }\end{array}$ & $\begin{array}{c}\text { Additional } \\
\text { energy } \\
\text { Generation } \\
(\%) \\
\end{array}$ & Advantage & Drawbacks \\
\hline Anchorage, AK & No Anneal & 0 & $\begin{array}{c}\text { Once every } \\
\text { year }\end{array}$ & .000345 & $\begin{array}{c}\text { Energy } \\
\text { generation } \\
\text { increased }\end{array}$ & N/A \\
\hline Casa Grande, AZ & 5 times/day & 34.35 & 1 time/day & 33.45 & $\begin{array}{c}\text { Reduces } \\
\text { annealing } \\
\text { associated } \\
\text { energy } \\
\text { consumption }\end{array}$ & $\begin{array}{c}\text { Energy } \\
\text { generation } \\
\text { decreased }\end{array}$ \\
\hline Apalachicola, FL & 6times/day & 33.17 & 1 time/day & 29.33 & $\begin{array}{c}\text { Reduces } \\
\text { annealing } \\
\text { associated } \\
\text { energy } \\
\text { consumption }\end{array}$ & $\begin{array}{c}\text { Energy } \\
\text { generation } \\
\text { decreased }\end{array}$ \\
\hline Aspen, CO & 1 time/day & 22.47 & 1 time/day & 22.47 & $\mathrm{~N} / \mathrm{A}$ & N/A \\
\hline
\end{tabular}




\section{Limitations and Future Work}

In this study three broad assumptions were made about the operating temperature as a function of ambient temperature. In reality it is unlikely that the PVT operating temperature could vary significantly and would depend on the designed solar thermal temperature and the flux as well as the ambient temperature, which affects the a-Si:H degradation behavior and electrical output. Modeling accurate PVT panel temperature as heat is transferred and solar flux is beyond the scope of this paper, but should be completed for future work along with experimental trials on manufactured a-Si:H PVT.

The primary limitation of this study is the accuracy of values of the degradation associated constants $\mathrm{k}_{\mathrm{dss}}$ and $u_{\mathrm{dss}}$, which were calculated linearly from the plots shown in Figure 1 and 2 . The parameters inside the range $25-90^{\circ} \mathrm{C}$ likely suffer from very little error, however, the extension off the range particularly to lower temperatures could be inaccurate. Based on the change of slope with decreasing temperature of the two parameters it is likely this would have the effect of underestimating the degradation at low temperatures, which may explain the outlier results seen for the Alaska case study. Future work is needed to run low temperature degradation/annealing experiments to provide more data points of $\mathrm{k}_{\mathrm{dss}}$ and $u_{d s s}$ values. A secondary problem associated with the degradation associated parameters is their value limits. The value of $u_{\text {dss }}$ falls with decrease in temperature and after certain temperature (approximately $2{ }^{\circ} \mathrm{C}$ ) the value of $u_{d s s}$ becomes negative. Theoretically it is not possible for $u_{d s s}$ to obtain negative value because that refers to rise in power rather than degradation. Thus when $u_{d s s}$ value is below 0 the value is set to 0 . Similarly the max limit for $\mathrm{k}_{\mathrm{dss}}$ value is 0.4642 and the parameter value cannot exceed the limit. Exceeding the limit deteriorates degradation behavior.

The calculation of appropriate dispatch strategy is limited only to electrical performance and thus does not include the thermal energy consumption associated with annealing. So these dispatch strategies should not be considered to be optimized. A study [3] investigating the exergy contributions between solar thermal and PV in PVT, found the electrical component dominates the overall exergy efficiency. This indicates that the dispatch strategies in this study will be a close approximation of the optimum, but the thermal losses with annealing and the overall effect of the operating temperature on the exergy efficiency of the PVT as a whole should be investigated in future work. In order to do a complete exergy or net energy analysis the energy 
used in the thermal annealing process must be quantified, which necessitates the quantification of the thermal energy component as well.

Other geographic and weather related effects can be taken into account to further refine future dispatch strategies for a-Si:H-based PVT such as including information from detailed studies of snow and its impact on solar energy devices [36] in snowbound areas. Moreover, using trade-off between the thermal power and electric power in PVT is possible and may be beneficial to be varied throughout the year given both weather and load considerations. Including such functionality into future models will give users more flexibility on usage of PVT and potentially improve the PVT operating efficiency further.

The results showed that annealing contributes to additional electricity generation in PVT in almost all cases. But annealing is also accompanied with PVT panel thermal energy consumption. Hence it is necessary to optimize the annealing cycle and obtain the most effective dispatch strategy for the total energy. This is left for future work, which should use exergy to determine the optimal routine.

\section{Conclusions}

The model presented here uses publicly-available data to implement suitable dispatch strategies and execute virtual performance analysis of PVT for any geographic location in the world. This study further refined the simulation of the optimal dispatch strategy for a-Si:H based PVT by studying annealing cycles and analysis of the degradation at other operating temperatures controlled by the ambient temperature. Four case studies were evaluated for the combinations of high and low solar flux and high and low average ambient temperature. Optimal dispatch strategies are found for a range of PVT thermal insulating effectivenesses. The results showed significantly more electricity generation (between 22-35\%) in all the cases except for those dominated by low temperatures and low solar fluxes. The results showed consistently high increases in electricity from PVT systems operated in high average temperature locations. These results further indicate that a-Si:H PV electrical performance can be improved in most populated regions in the world by integrating it into a PVT device and using spike annealing to reverse the SWE effect.

\section{Acknowledgements}


This work was supported by the Winn Fellowship and the authors would like to acknowledge helpful input from A.H. Vora, S.K. Debnath, and M.J.M. Pathak. 


\section{References}

[1] NPD Solarbuzz, Solar Market Research Analysis. < http://www.solarbuzz.com/goingsolar/understanding/technologies>; 2014

[2] Saga T. Advances in crystalline silicon solar cell technology for industrial mass production. NPG Asia Materials 2010; 2:96-102. http://dx.doi.org/10.1038/asiamat.2010.82.

[3] Pathak MJM, Sanders PG, Pearce JM. Optimizing limited solar roof access by exergy analysis of solar thermal, photovoltaic, and hybrid photovoltaic thermal systems. Applied Energy 2014;120:115-24. http://dx.doi.org/10.1016/j.apenergy.2014.01.041.

[4] Tripanagnostopoulos Y, Nousia T, Souliotis M, Yianoulis P. Hybrid photovoltaic/thermal solar systems. Solar Energy 2002;72:217-34. http://dx.doi.org/10.1016/S0038-092X(01)00096-2.

[5] Huang BJ, Lin TH, Hung WC, Sun FS. Performance evaluation of solar photovoltaic/thermal systems. Solar Energy 2001;70:443-8. http://dx.doi.org/10.1016/S0038092X(00)00153-5.

[6] Derewonko P, Pearce JM. Optimizing design of household scale hybrid solar photovoltaic - combined heat and power systems for Ontario. In: 34th Proceedings of IEEE Photovoltaic Specialists Conference (PVSC); 2009. pp. 001274-9. doi: 10.1109/PVSC.2009.5411247.

[7] Assoa YB, Menezo C, Fraisse G, Yezou R, Brau J. Study of a new concept of photovoltaic-thermal hybrid collector. Solar Energy 2007;81:1132-43. http://dx.doi.org/10.1016/j.solener.2007.04.001.

[8] Vorobiev YV, Gonzalez-Hernandez J, Kribus A. Analysis of potential conversion efficiency of a solar hybrid system with high-temperature stage. J Sol. Energ Eng 2006;128:25860. http://dx.doi.org/10.1016/j.solener.2005.04.022.

[9] Kalogirou SA, Tripanagnostopoulos Y. Hybrid PV/T solar systems for domestic hot water and electricity production. Energ Convers Manage 2006;47:3368-82. http://dx.doi.org/10.1016/j.enconman.2006.01.012. 
[10] Jardan RK, Nagy I, Cid-Pastor A, Leyva R, El Aroudi A, Martinez-Salamero L. Combined photovoltaic/thermal energy system for stand-alone operation. Proc IEEE Int Sympos Indust Electron; 2007:2403-8. http://dx.doi.org/10.1109/ISIE.2007.4374983.

[11] Calise F, d'Accadia MD, \& Vanoli L. Design and dynamic simulation of a novel solar trigeneration system based on hybrid photovoltaic/thermal collectors (PVT). Ener. Conv. and Management; 2012:60, 214-225. http://dx.doi.org/10.1016/j.enconman.2012.01.025

[12] Chow TT. A review on photovoltaic/thermal hybrid solar technology. Appl Energy 2010;87:365-79. http://dx.doi.org/10.1016/j.apenergy.2009.06.037.

[13] Virtuani A, Pavanello D, Friesen G. Overview of temperature coefficients of different thin film photovoltaic technologies. In: 25th European photovoltaic solar energy conference and exhibition/5th World conference on photovoltaic energy conversion; 2010. pp. 6-10. doi:

10.4229/25thEUPVSEC2010-4AV.3.83

[14] Wormser P, Strong S. Evaluation of the potential for use of new thin film photovoltaic materials as selective surfaces for solar thermal absorbers in flatplate combined photovoltaic/thermal collectors. ASHRAE Final Report \#1109-RP, 2006, pp. 1-23.

[15] Schweizer E, Enecolo AG. LESO-PB, new generation of hybrid solar PV/T collectors. Final Report DIS 56360/16868, 2000, pp. 1-55.

[16] Fraisse G, Ménézo C, Johannes K. Energy performance of water hybrid PV/T collectors applied to combisystems of Direct Solar Floor type. Solar Energy 2007;81:1426-38. http://dx.doi.org/10.1016/j.solener.2006.11.017.

[17] Zondag HA, de Vries DW, van Helden WGJ, van Zolingen RJC, van Steenhoven AA. The yield of different combined PV-thermal collector designs. Solar Energy 2003;74:253-69. http://dx.doi.org/10.1016/S0038-092X(03)00121-X.

[18] Vorobiev Y, González-Hernández J, Vorobiev P, Bulat L. Thermal-photovoltaic solar hybrid system for efficient solar energy conversion. Solar Energy 2006;80:170-6. http://dx.doi.org/10.1016/j.solener.2005.04.022. 
[19] Charalambous PG, Maidment GG, Kalogirou SA, \& Yiakoumetti K. Photovoltaic thermal (PV/T) collectors: A review. Applied Thermal Engineering 2007; 27(2), 275-286. http://dx.doi.org/10.1016/j.applthermaleng.2006.06.007

[20] Pathak MJM, Pearce JM, Harrison SJ. Effects on amorphous silicon photovoltaic performance from high-temperature annealing pulses in photovoltaic thermal hybrid devices. Solar Energy Materials and Solar Cells. 2012;100:199-203. http://dx.doi.org/10.1016/j.solmat.2012.01.015.

[21] Pathak MJM, Girotra K, Harrison SJ and Pearce JM, The effect of hybrid photovoltaic thermal device operating conditions on intrinsic layer thickness optimization of hydrogenated amorphous silicon solar cells, Solar Energy. 2012; 86: 2673-2677. http://dx.doi.org/10.1016/j.solener.2012.06.002.

[22] Wronski CR, Pearce JM, Deng J, Vlahos V, Collins RW. Intrinsic and light induced gap states in a-Si:H materials and solar cells the effects of microstructure. Thin Solid Films 2004;451e452:470-5. http://dx.doi.org/10.1016/j.tsf.2003.10.129.

[23] Staebler DL, Wronski CR. Reversible conductivity changes in discharge produced amorphous Si. Appl Phys Lett 1977;31:292-4. http://dx.doi.org/10.1063/1.89674.

[24] Fritzsche H. Development in understanding and controlling the Staebler-Wronski effect in a-Si:H. Annu Rev Mater Res 2001;31:47-79.

[25] Deng J, Albert ML, Pearce JM, Collins RW, Wronski CR. The nature of native and light induced defect states in i-layers of high quality a-Si:H solar cells derived from dark forward bias currentevoltage characteristics. Mater Res Soc Sympos Proc 2005;862. http://dx.doi.org/10.1557/PROC-862-A11.4. A11.4.

[26] Klaver A, van Swaaij RACMM. Modeling of light-induced degradation of amorphous silicon solar cells. Solar Energy Mater Solar Cells 2008;92:50-60. http://dx.doi.org/10.1016/j.solmat.2007.08.010.

[27] Lund, CP, Luczak K, Pryor T, Cornish JCL, Jennings PJ, Knipe P, \& Ahjum F. Field and laboratory studies of the stability of amorphous silicon solar cells and modules. Renewable Energy 2001; 22(1), 287-294. http://dx.doi.org/10.1016/10.1016/S0960-1481(00)00045-8 
[28] Rozario J, Vora AH, Debnath SK, Pathak MJM, Pearce JM. The effects of dispatch strategy on electrical performance of amorphous silicon based solar photovoltaic thermal systems. Renewable Energy. Renewable Energy. 2014;16:459-465. doi:

10.1016/j.renene.2014.02.029

[29] National Solar Radiation Database, National Renewable Energy Laboratory, Golden, Colorado. <http://rredc.nrel.gov/solar/old data/nsrdb/>; 2014.

[30] National Climactic Data Center, National Oceanic and Atmospheric Administration, Silver Spring, Maryland.

<http://www.ncdc.noaa.gov/oa/climate/severeweather/hurricanes.html>; 2014.

[31] NREL Solar Propector, National Renewable Energy Laboratory, Golden, Colorado. $<$ http://maps.nrel.gov/prospector>; 2014.

[32] Wilcox S. National solar radiation database 1991-2010 update: user's manual. NREL

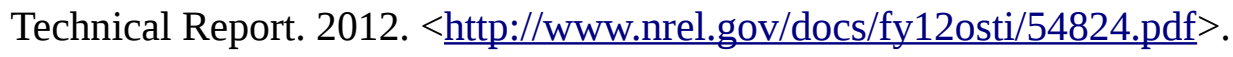

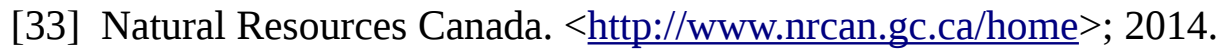

[34] Rozario, J. “The effect of annealing on amorphous silicon based solar photovoltaic thermal system (PV/T) and appropriate global dispatch strategies. 2014. Msc Thesis The Michigan Technological University.

[35] Yang L, Chen L. "Fast” and “slow" metastable defects in hydrogenated amorphous silicon. Appl. Phys. Lett. 1993;63:400-402. http://dx.doi.org/10.1063/1.110031

[36] Pearce JM, Koval RJ, Niu X, May SJ, Collins RW, Wronski C R. The 'fast' and 'slow' light induced defects in diluted and undiluted hydrogenated amorphous silicon solar cells and materials. In Proc. 17th Eur. Photovoltaic Solar Energy Conf.; 2002. pp. 2842-2845.

[37] Andrews RW, Pollard A, Pearce JM, “The Effects of Snowfall on Solar Photovoltaic Performance. Solar Energy. 2013;92: 84-97. doi: 10.1016/j.solener.2013.02.014 


\section{Figure Captions}

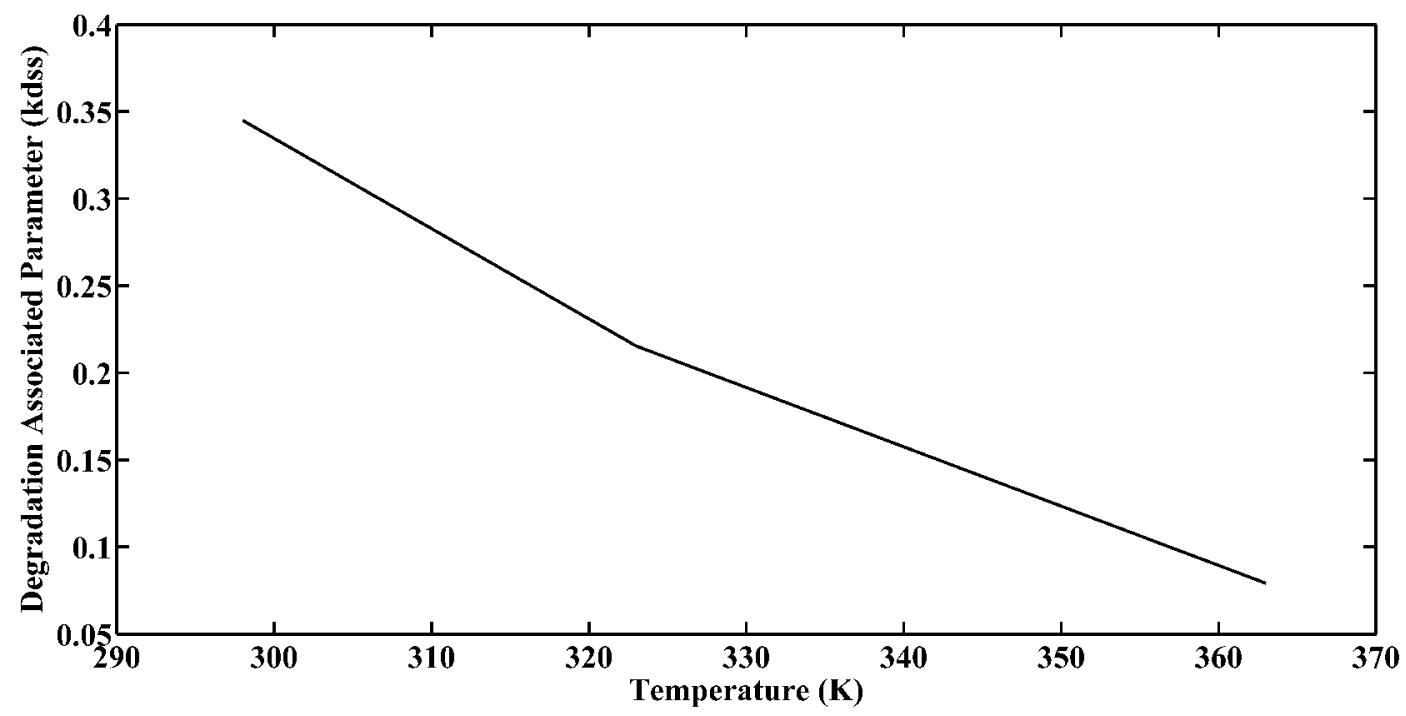

Fig. 1 Degradation associated parameter $\mathrm{k}_{\mathrm{dss}}$ against temperature

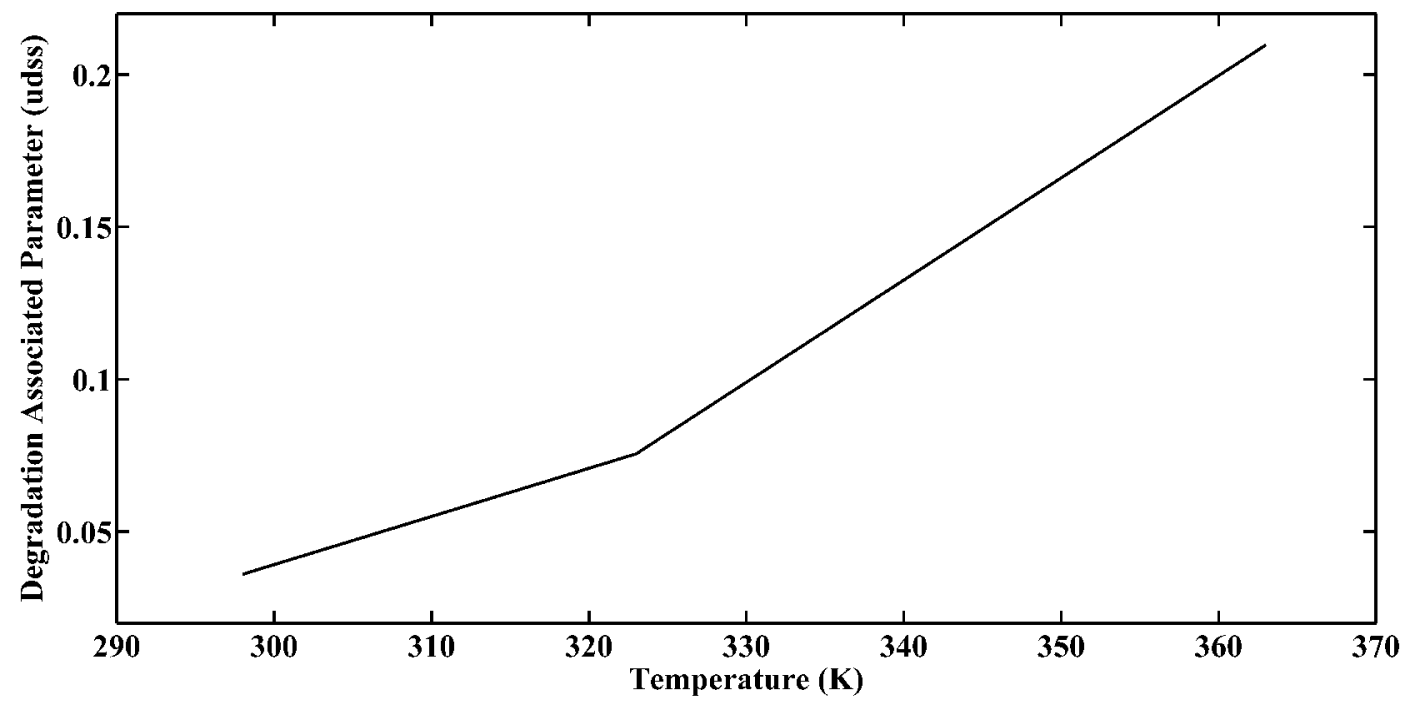

Fig. 2 Degradation associated parameter $u_{d s s}$ against temperature 


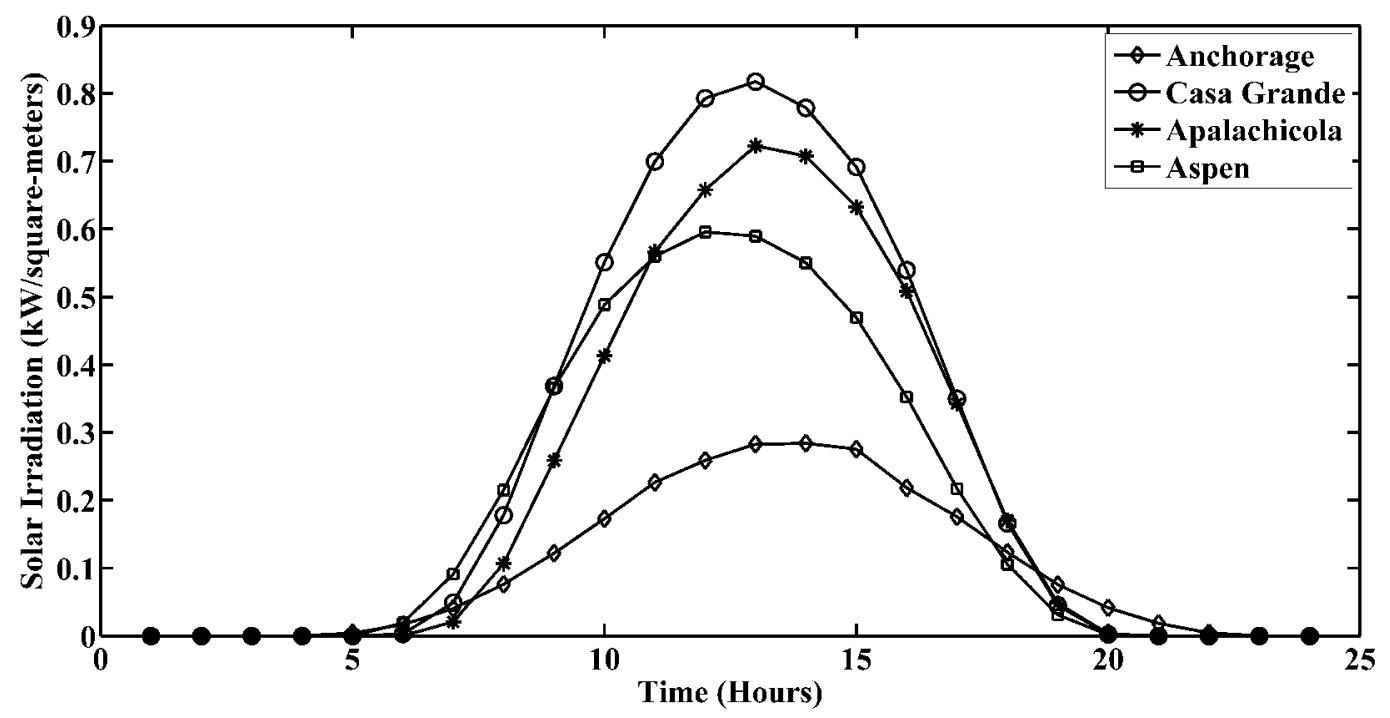

Fig 3 Average hourly solar irradiation per day for the four cities

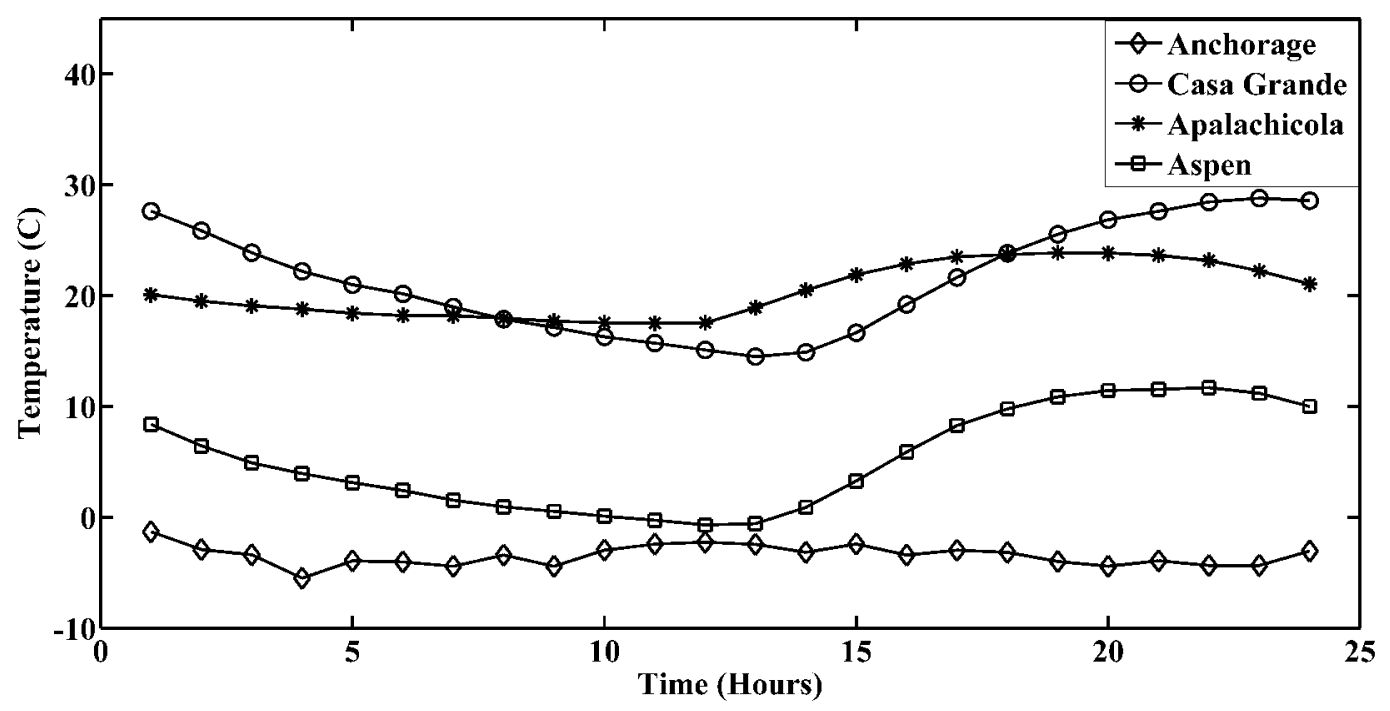

Fig. 4 Average hourly temperature readings per day for the four cities 


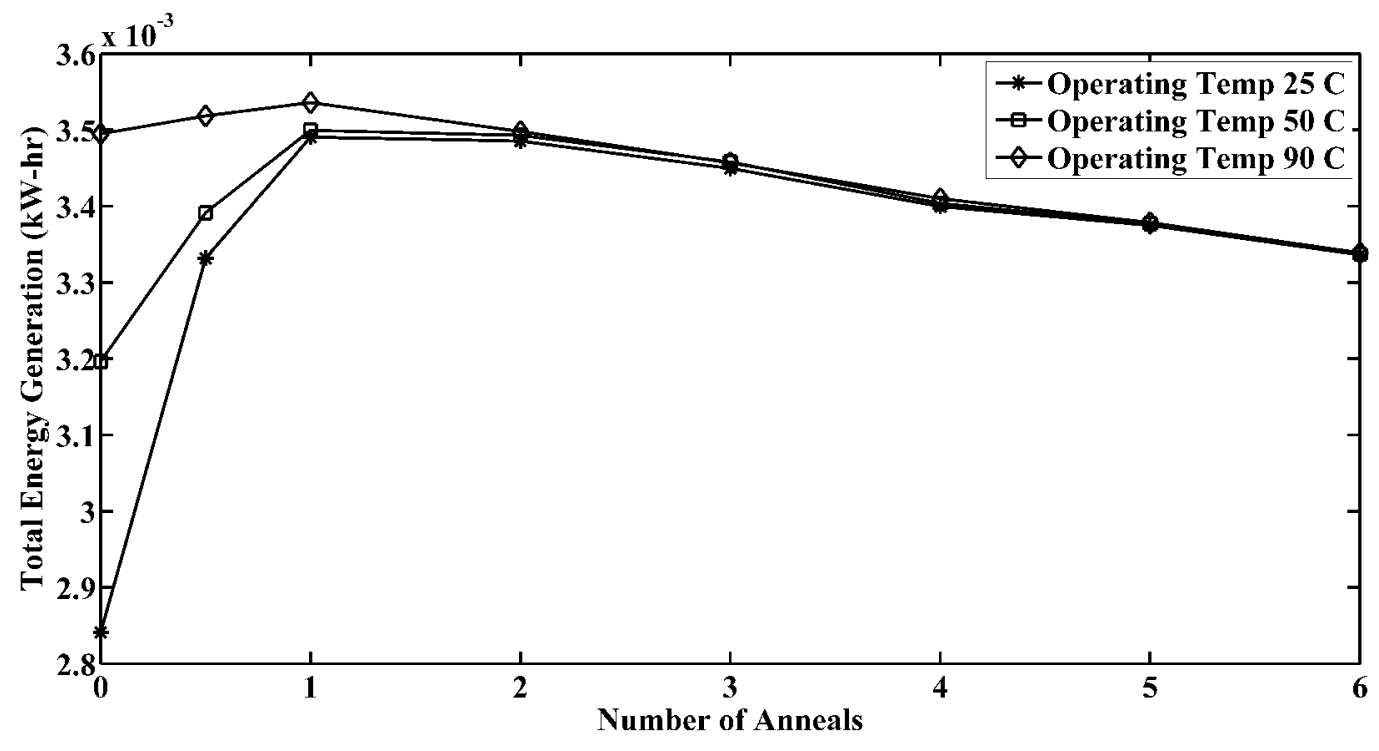

Fig. 5 Total electricity generation over a year under different annealing conditions in Anchorage, AK at sustained operating temperatures

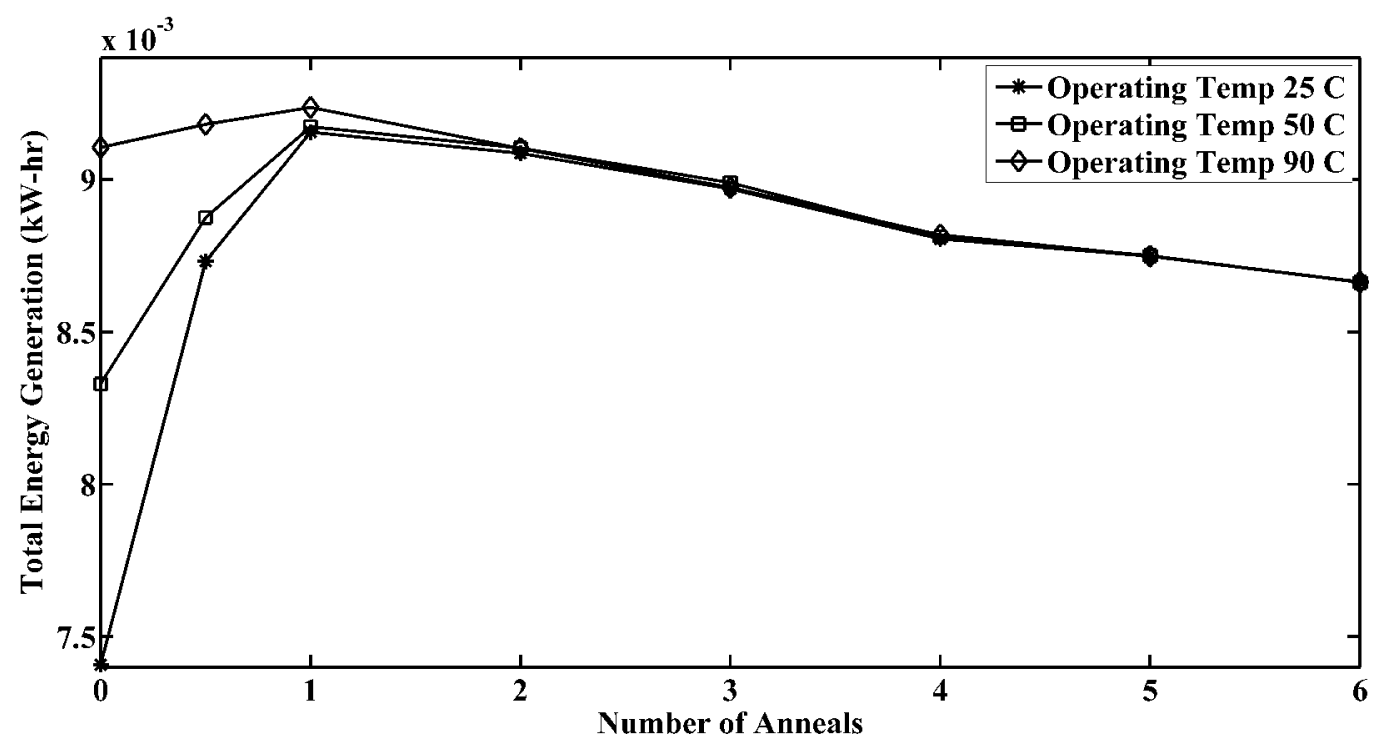

Fig. 6 Total electricity generation over a year under different annealing conditions in Casa Grande, AZ at sustained operating temperatures 


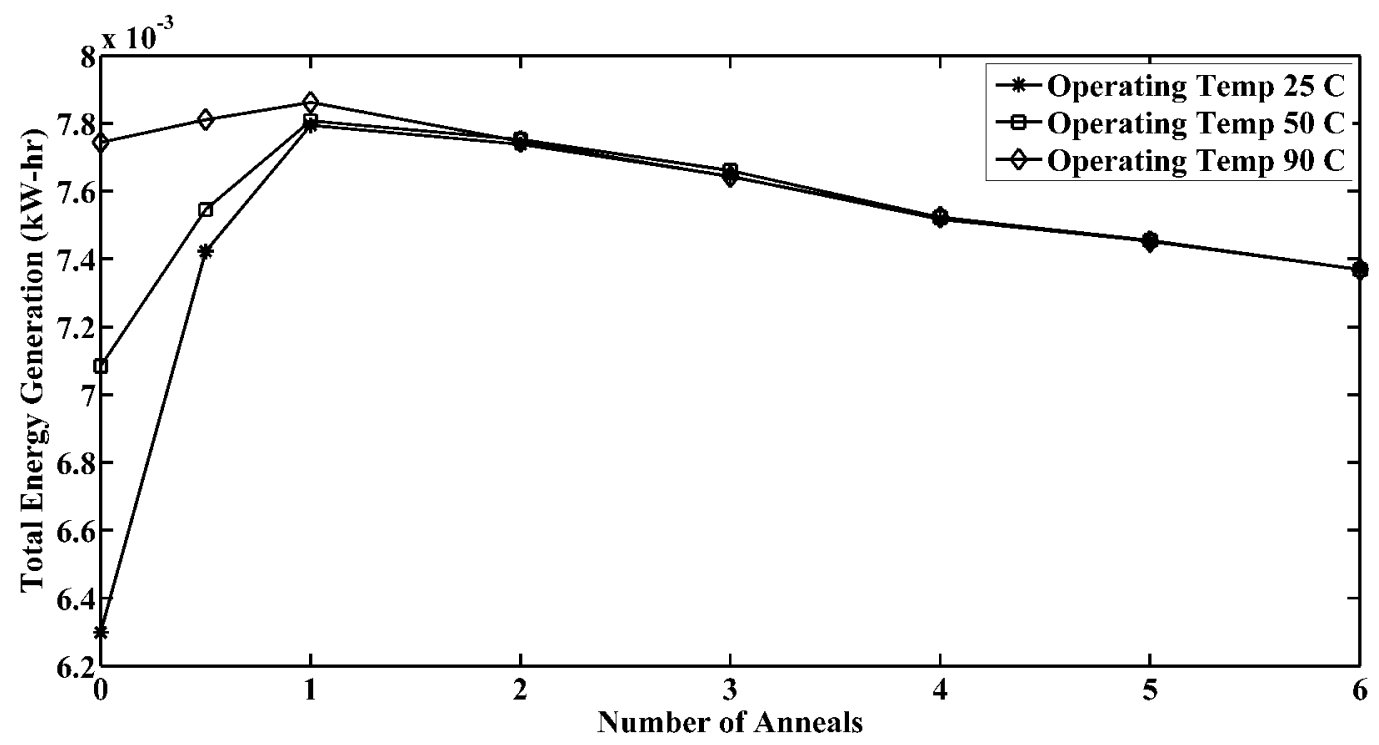

Fig. 7 Total electricity generation over a year under different annealing conditions in Apalachicola, FL at sustained operating temperatures

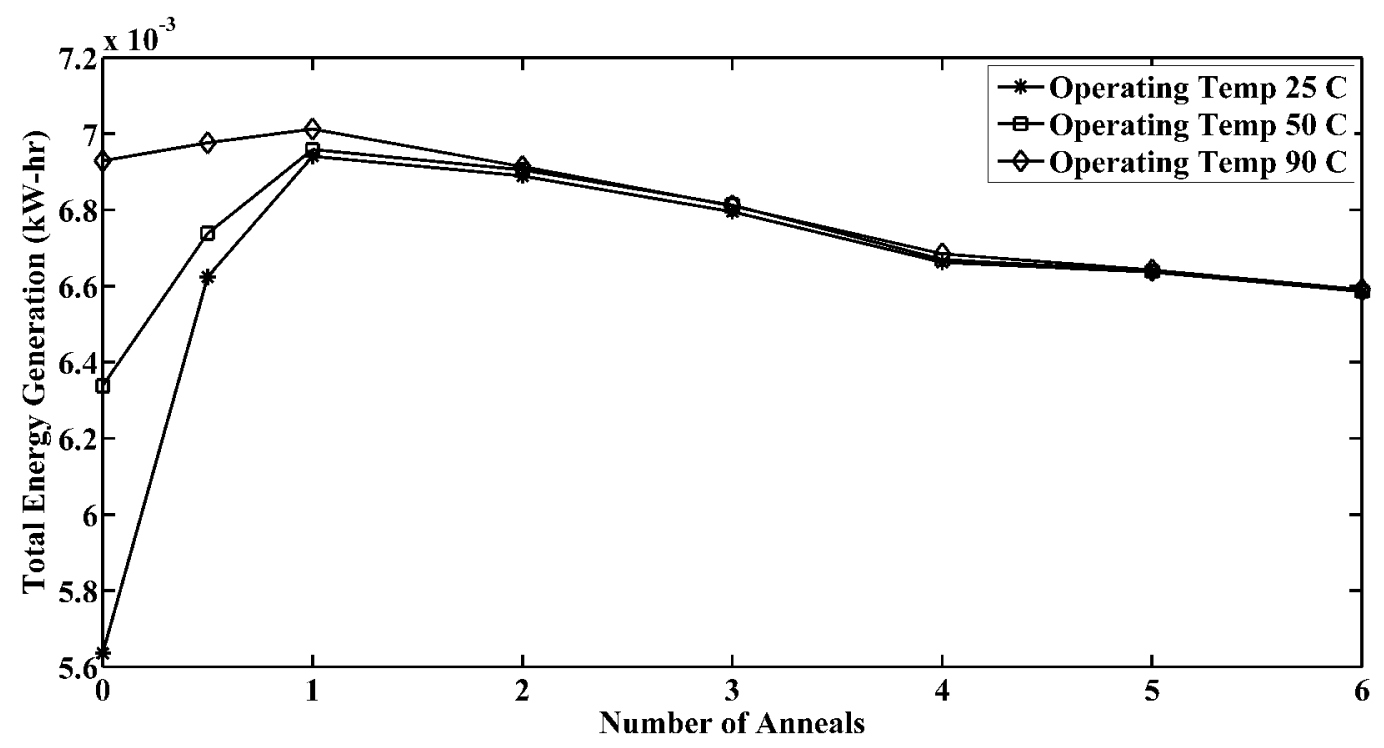

Fig. 8 Total electricity generation over a year under different annealing conditions in Aspen, CO at sustained operating temperatures 


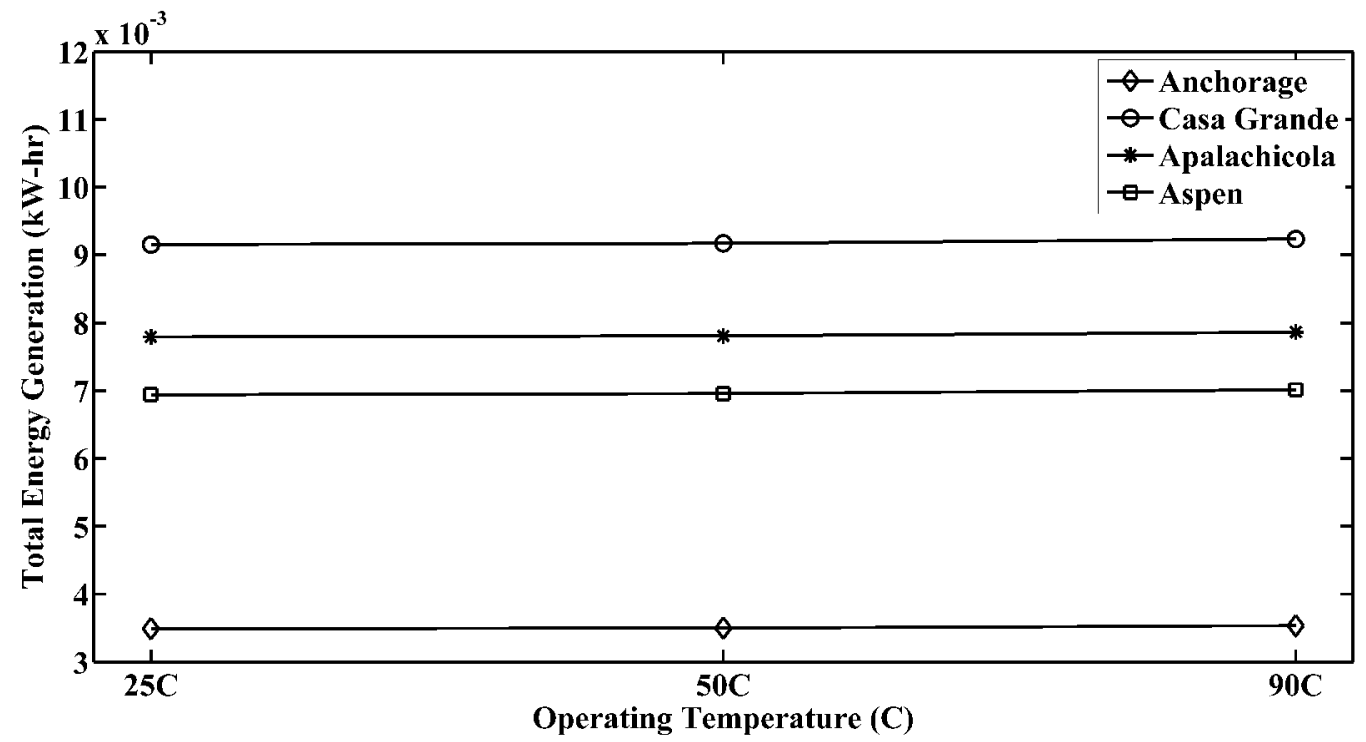

Fig. 9 Maximum electricity generation (obtained for annealing one time every day) over a year in the four cities at sustained operating temperatures

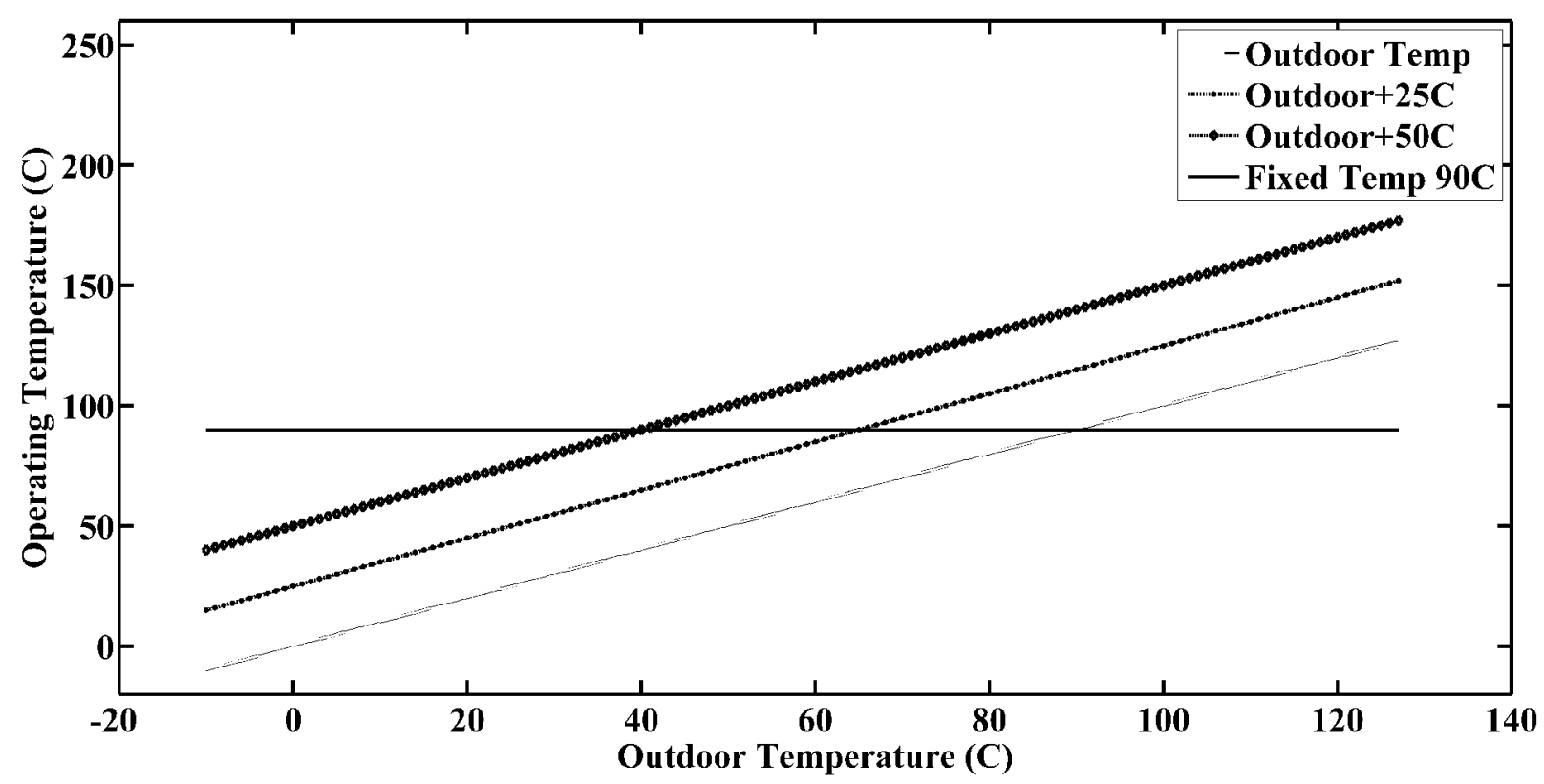

Fig. 10 Sensitivity study with different outdoor operating conditions 


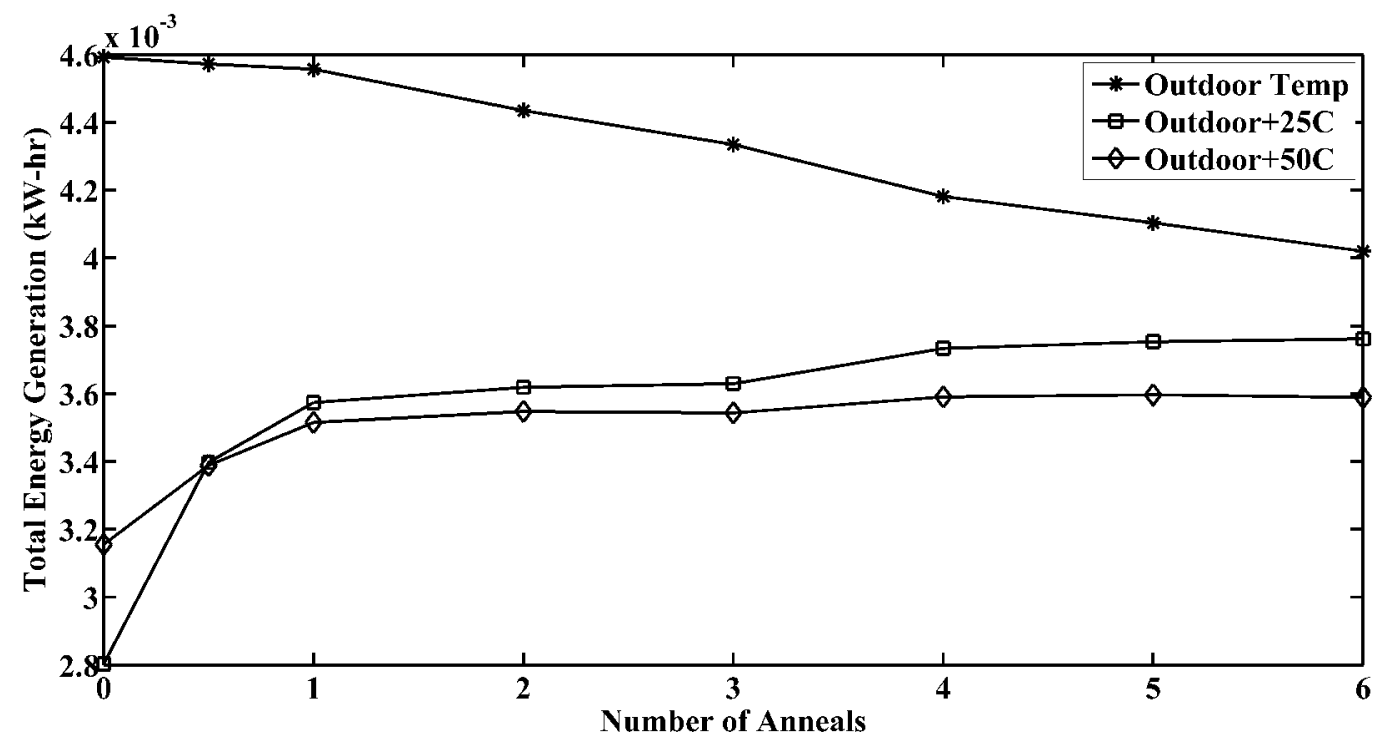

Fig. 11 Total electricity generation over a year under different annealing cycles in Anchorage, AK at outdoor operating conditions

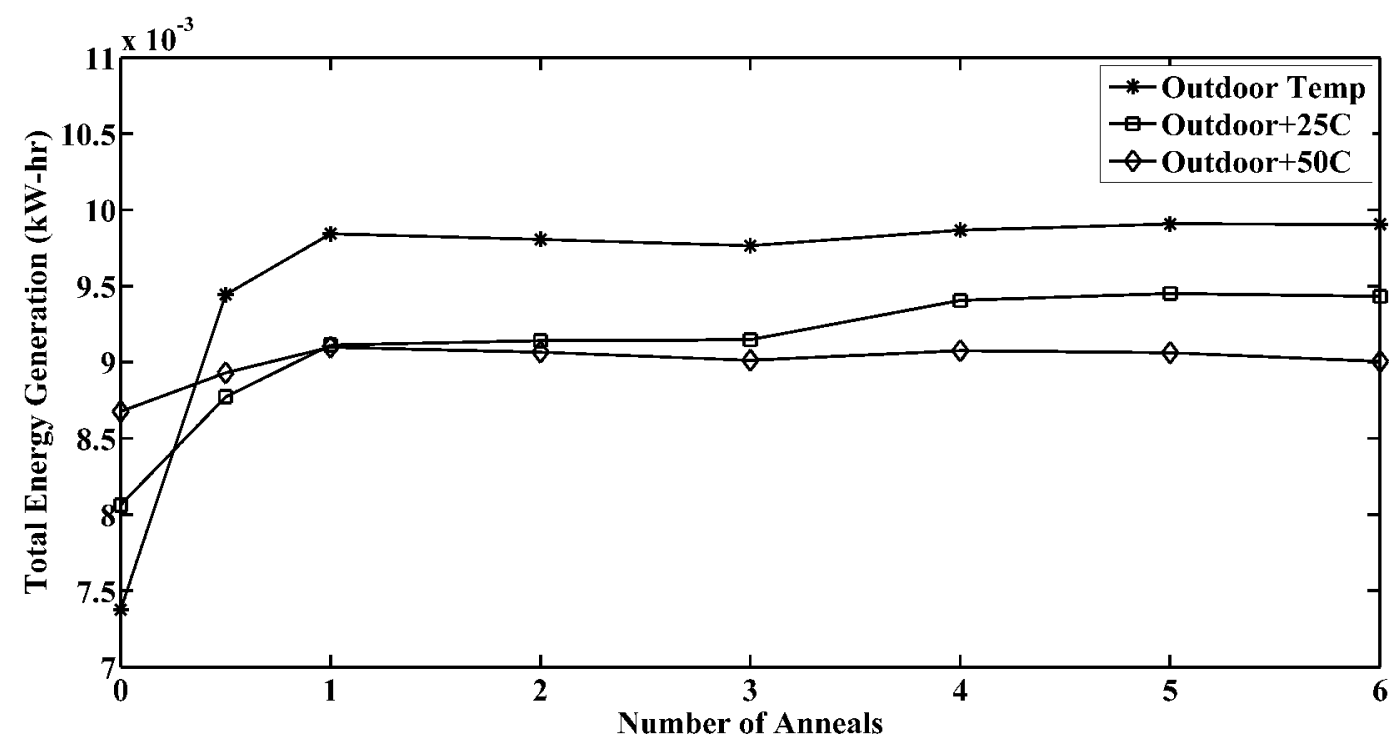

Fig. 12 Total electricity generation over a year under different annealing cycles in Casa Grande, $\mathrm{AZ}$ at outdoor operating conditions 


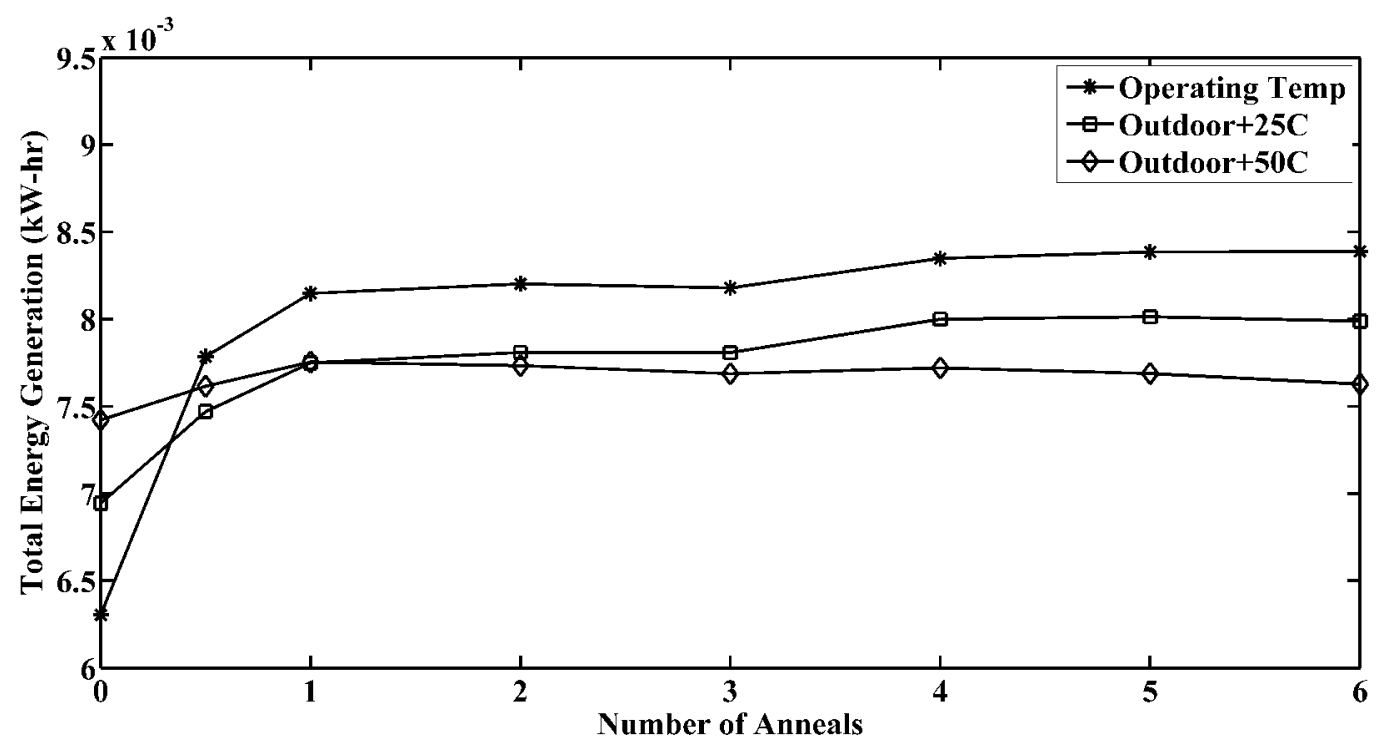

Fig. 13 Total electricity generation over a year under different annealing cycles in Apalachicola, FL at outdoor operating conditions

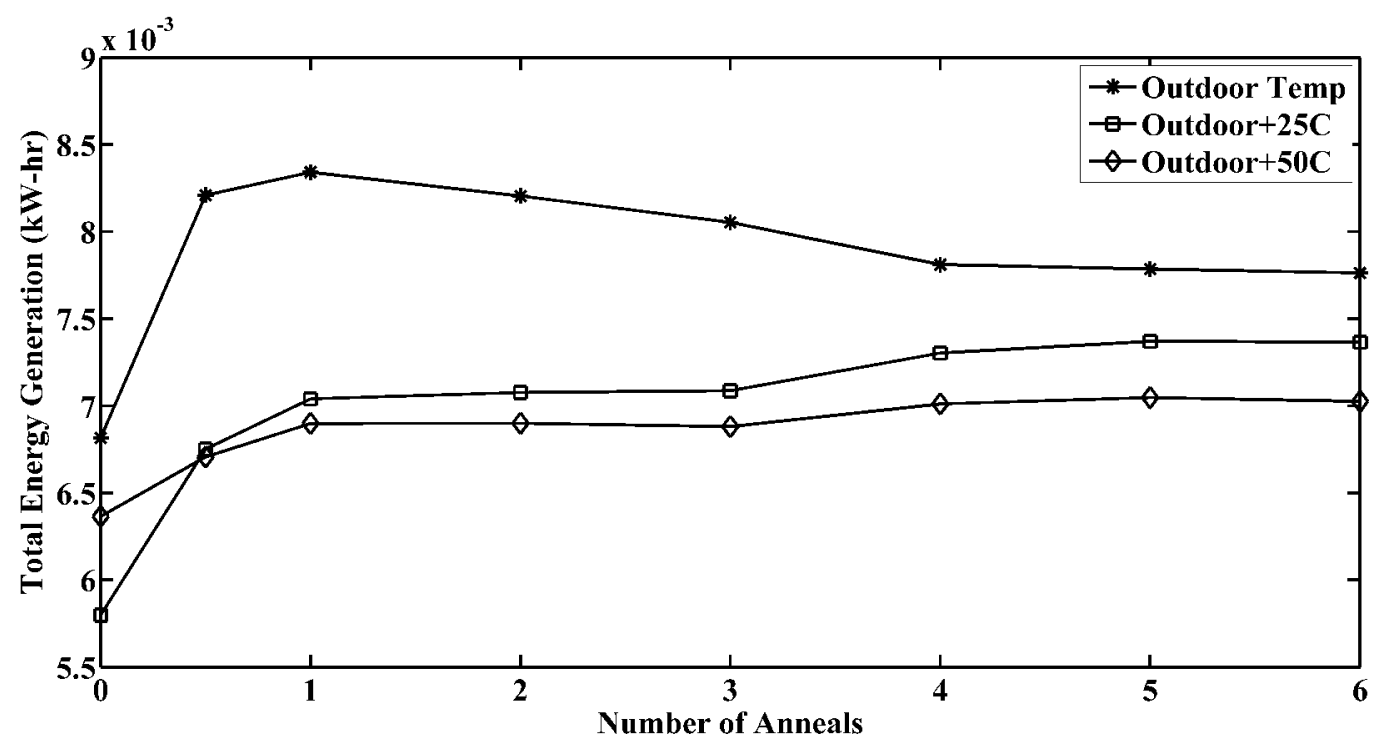

Fig. 14 Total electricity generation over a year under different annealing cycles in Aspen, CO at outdoor operating conditions 


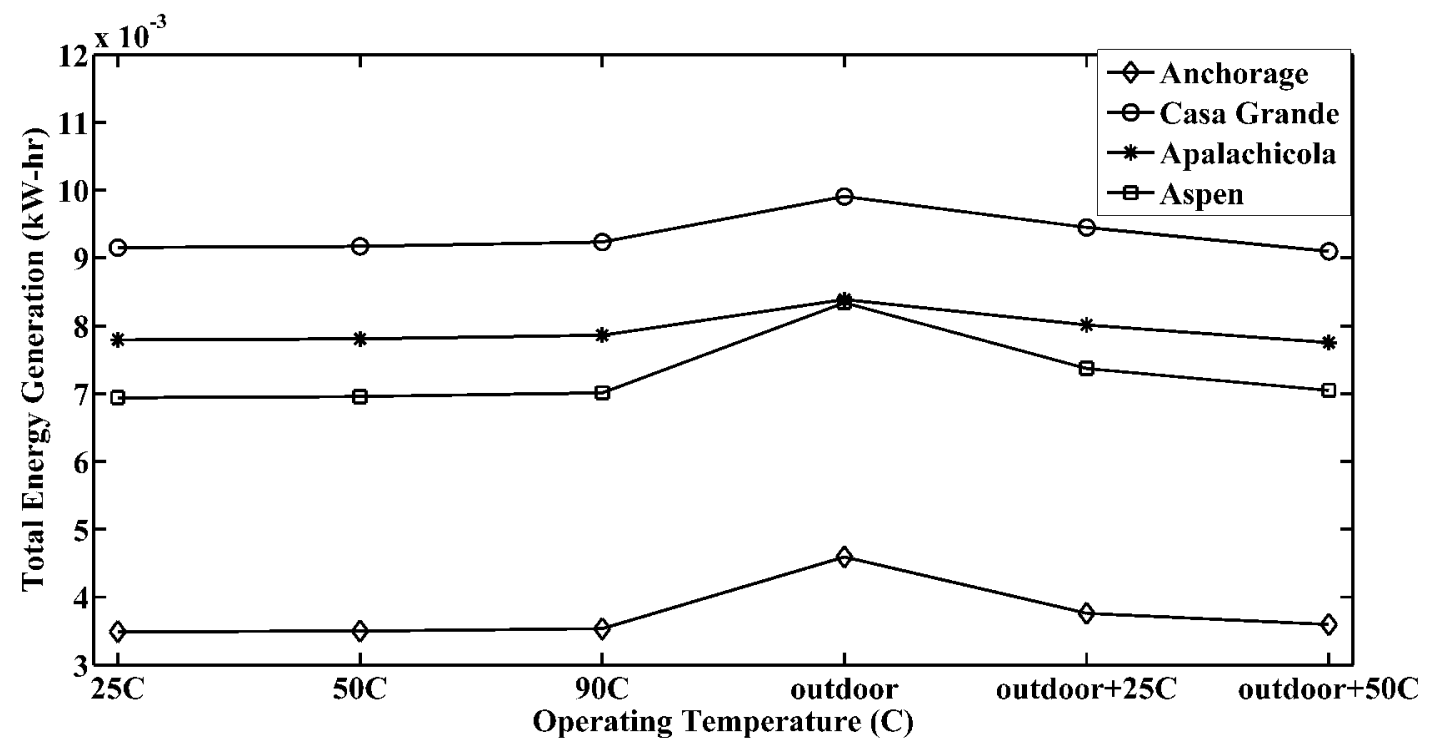

Fig. 15 Maximum electricity generation over a year for the four cities at sustained temperature (anneal cycle is one time per day) and outdoor operating conditions (anneal cycle varies from one place to another) 